\title{
Species Composition and Distribution Pattern of Longhorn Beetles (Coleoptera: Cerambycidae) across India
}

\author{
B. Kariyanna ${ }^{1,3}$, M. Mohan ${ }^{2}$, Rajeev Gupta ${ }^{1}$ and N. Bakthavatchalam ${ }^{2}$ \\ ${ }^{1}$ Indira Gandhi Krishi Vishwavidyalaya, Raipur, Chhattisgarh-492012, India \\ ${ }^{2}$ ICAR-National Bureau of Agricultural Insect Resources, Bangalore, Karnataka-560024, India \\ ${ }^{3}$ University of Agriculture Science, Raichur, Karnataka-584101, India \\ *Corresponding author
}

\begin{tabular}{|c|c|}
\hline & A B S T R A C T \\
\hline Keywords & \multirow{7}{*}{$\begin{array}{l}\text { The longhorn beetles are distributed world-wide from sea level to mountain } \\
\text { region as high as } 4,200 \text { meter altitude wherever their host plants are found. A } \\
\text { complete checklist of longhorn beetles includes } 1555 \text { valid species recorded so } \\
\text { far from India. Out of these species, the region wise distribution are: } 592 \text { from } \\
\text { North-Eastern states, } 272 \text { from Northern India, } 431 \text { from Southern India, } 47 \\
\text { from Central India, } 48 \text { from Western India, } 348 \text { from Eastern India, } 18 \text { from } \\
\text { North-Western India, } 57 \text { from India Orientals and } 121 \text { from Indian Islands. } \\
\text { The maximum numbers of species were recorded from North-Eastern India } \\
(38.1 \%) \text { followed by southern part }(28 \%) \text { and West Bengal alone accounted } \\
\text { over } 22 \text { per cent longhorn beetles. }\end{array}$} \\
\hline Longhorn & \\
\hline $\begin{array}{l}\text { Beetles, } \\
\text { Snecies }\end{array}$ & \\
\hline Composition, & \\
\hline & \\
\hline Article Info & \\
\hline $\begin{array}{l}\text { Accepted: } \\
\text { 17 April } 2017 \\
\text { Available Online: } \\
10 \text { May } 2017\end{array}$ & \\
\hline
\end{tabular}

\section{Introduction}

The kingdom Animalia is represented by $1,552,319$ species under 40 phyla. Among these, the phylum Arthropoda alone represents $1,242,040$ species, or about 80 per cent of the total. The most successful group, the Insecta $(1,020,007$ species), accounts for about 66 per cent of all animals. The most diverse and successful insect order, Coleoptera $(387,100$ species), represents about 38 per cent of all insect species (Zhang, 2011). The Cerambycidae is one of the biggest families of Coleoptera represented by more than 35,000 species described under 4,000 genera (Lawrence, 1982; Švácha and Lawrence, 2014). The Family name
Cerambycidae originated from the Greek word "Cerambis" meaning "a horned beetle".

The Cerambycidae beetles are distributed world-wide from sea level to mountain sites as high as 4,200 m elevation wherever their host plants are found (Bezark et al., 2013). Though the members of the family Cerambycidae are cosmopolitan, the largest subfamilies like Lamiinae, Cerambycinae and Prioninae are most diverse in the tropical and subtropical parts of the world (Berkov \& Tavakilian 1999, Berkov et al., 2000). The beetles which are developing in timbers, are easily transported inside the timber or under 
the bark of tree logs, and thus expand their geographical range. Some are unable to develop in a new area, whereas others succeed in establishing a population and can be considered as potential pests (Friedman, 2008). However, the main factors governing long-horned beetles distribution are the climatic and availability of suitable host plants. Past climate changes, result into evolution and spread of past floras, this made a profound influence on the distributional and evolutionary history of the survival representatives of Cerambycidae family in current days (Slipinski and Escalona, 2013).

\section{Materials and Methods}

Extensive surveys were carried to find out the beetles diversity and their distribution range in the natural stands in years 2015 and 2016 by IGKV, Raipur in collaboration with ICARNBAIR, Bengaluru from major states of India (Fig. 1).

\section{Analysis of longhorn beetles distribution}

As per the study of Kariyanna (2016), the complete checklist information of Indian longhorn beetles was analysed to understand the various parameters of the taxonomy of the group. Based on the checklist information, sub-family, tribe, genera and species distribution across the India were analysed. This analysis was primarily made to understand the general situation of the taxonomic status of the group in the country and to appreciate the need for additional work to make it more comprehensive. The ultimate goal of this analysis was to answer "How many more species of Cerambycid beetles are there to be discovered in India?"

\section{Area covered for the study}

The longhorn beetles were collected mainly by light traps operated during different periods of the year at Western Ghats of
Karnataka (Bangalore, Mandya, Kolar, Mudigere, Chettahalli, Madikeri and Shimogha), Tamil Nadu (Hosur, Yercaud, Madurai, Periyakulam, Kodaikanal and Thadiyankudisai) Kerala (Trivendrum, Pattambi and Peechi), Maharashtra (Pune), Assam, Mizoram, Andhra Pradesh (Madanapalli, Chithoor and Tirupathi), Andaman and Nicobar Islands (Port Blair, little Andaman and Great Nicobar), Jammu \& Kashmir (Srinagar, Gulmarg, Shalimar, Tangmarg, Kargil, and Leh) and Himachal Pradesh (Palampur, Dalhousie and Solan). The places covered in Chhattisgarh includes Ambikapur, Bastar (Jagdalpur), Bilaspur, Kawardha, and Raipur. Many specimens were obtained from students, research scholars and Scientists across the country. Museum collections of ICAR-National Bureau of Agriculture Insect Resources (NBAIR), Bangalore, Zoological Survey of India (ZSI), Calcutta, Kerala Forest Research Institute (KFRI), Peechi, Kerala and Forest Research Institute (FRI), Dehradun were also examined (Fig. 1).

\section{Other sources of longhorn beetles used for investigation}

The collections maintained at Department of Entomology, Indira Gandhi Krishi Vishwavidyalaya (IGKV), Raipur; R.M.D. College of Agriculture and Research Station, Raghavpuri, Ambikapur; T. C. B. College of Agriculture and Research Station, Sarkanda, Bilaspur; S. G. College of Agriculture and Research Centre, Bastar, Jagdalpur; S. K. College of Agriculture and Research Station, Ghotiya, Kawardha; University of Agriculture Science (UAS), Raichur; College of Agriculture, BhimarayanaGudi; University of Agriculture Science (UAS) GKVK, Bangalore; College of Agriculture, Mandya; College of Agriculture, Chintamani and College of Agriculture, Hassan were also consulted. 


\section{Results and Discussion}

Longhorn beetles (Coleoptera: Cerambycidae) are the major pestiferous insects of perennial trees in India. They attack both perennials such as coffee, cashew, mango fruit crops etc. and semiperennials such as mulberry and jasmine. Larvae feed on the trunk, hardwood, softwood, deadwood and adults feed on leaves and flowers and even fruits. Although, a large number of species of Cerambycidae are considered pests, the identity of many of these species is yet to be clearly established. Majority of these longhorn species belonging to the subfamilies Lamiinae and Cearmbycinae.

Inventory of longhorn beetles of Arunachal Pradesh, Tripura, West Bengal, Meghalaya, Sikkim, Uttarakhand and Tamil Nadu were made available by Zoological survey of India in its various publications. Mukhopadhyay and Biswas (2000) consolidated the information available on Cerambycid fauna of Meghalaya. They reported 71 species under 44 genera and five subfamilies. Ofthem subfamily Lamiinae recorded the maximum number of species (47), followed by Cerambycinae (16), Prioninae (7) and Lepturinae (1). The cerambycid fauna of Sikkim is not extensively surveyed and there is only record of 75 species under 49 genera belonging to four subfamilies through the publication of Mukhopadhyay and Halder (2003).

In Tamil Nadu, 181 longhorn species constituting 10.8 per cent of Indian species, under 103 genera and five subfamilies were listed. The Western Ghats exhibited the highest degree of endemism with 84 species and five species were common to both Eastern and Western Ghats (Namboodiri and Thirumalai, 2009). A consolidated key to the tribes of Indian Lamininae has also been prepared by them for the first time. From
Tripura, Agarwala and Bhattacharjee (2012) listed 14 Lamiinae, nine Cerambycinae and one Prioninae. Among these 11 were new to Tripura. Mukhopadhyay (2011) reported 41 species of Cerambycid beetles from Uttarakhand state. Of them subfamily Lamiinae shared maximum number of species (25), followed by Cerambycinae (14), Prioninae (1) and Lepturinae (1). A first consolidated list of 146 species of Cerambycidae under 84 genera of 38 tribes belonging to four subfamilies from West Bengal was prepared (Mitra et al., 2015). Of them, the subfamily Lamiinae shared the maximum number of species (79), followed by Cerambycinae (56), Prioninae (10) and Lepturinae (1). A total of 49 species of cerambycids belonging to three subfamilies were recorded from Arunachal Pradesh. The subfamily Lamiinae was found to be the dominant with 28 species followed by Cerambycinae (11 species). Subfamily Prioninae included 10 species (Kumawat et al., 2015).

Three species of longhorn beetles viz., Acalolepta rusticatrix (Fabricius) (Agniini), Olenecamptus bilobus (Fabricius) (Doracoschematini) and Gnomanico barica Breuning (Gnomini) belonging to the subfamily Lamiinae were reported as new records from the Little Nicobar Island by Mitra (2013). Abryna regispetri Paiva, 1860 (Lamiinae: Pteropliini) collected in Tripura is a new record to India (Ghate and Agrawala, 2015). So far known it was known only from Laos, Myanmar, Malaysia, China, Borneo and Thailand.

The longhorn beetles of Prioninae subfamily are mostly borers, whose larvae feed on rotting wood or roots. Few members of the subfamily make tunnel freely in the soil alongside the roots of trees. These beetles fall in the group of heartwood borers and thus reflecting its immense importance in the 
timber economy of the country. They are cosmopolitan in distribution and include many of the largest species of the Coleoptera order. Prioninae may be readily recognized by the prothoracic possession of the sharp lateral margins. The Indian genera generally bear coarsely facetted eyes, and the species, more or less, are restricted in their range of coloration between black and lighter shades of brown which verge on red and yellow. World catalogue of prioninae was recently published by Delahaye (2012). Till date, the most comprehensive information on Indian Prioninae was provided in 'The Fauna of British India including Ceylon and Burma' by Gahan in 1906. Subsequently, Stebbing (1914) and Beeson (1941) published literatures on biology and ecology of these beetles. The first consolidated checklist of Indian Prioninae including 47 species belonging to 23 genera and nine tribes has been provided by Majumder et al., (2014).

The taxonomic work on Cerambycid beetles of Madhya Pradesh indicated a total of 18 species. The list mentioned eight species from Lamiinae, seven species from Cerambycinae and three species from Prioninae (Majumder et al., 2015).

A total of 107 longhorn species were collected and preserved at the ICAR-NBAIR National Insect Repository by the author. This is accounted for about 0.8 per cent of the total longhorn taxa known from India. The collection included 56 species of Lamiinae, 34 species of Cerambycinae, 14 species of Prioninae, 2 species of Lepturinae and 1 species of Vesperinae (Vesperidae) (Table 1).

Table.1 Representation of different subfamilies, tribes, genus and species of long-horn beetles from museum collection of the ICAR-NBAIR, against total Indian species

\begin{tabular}{lccccc}
\hline Subfamily & $\begin{array}{c}\text { Tribes in } \\
\text { each Sub- } \\
\text { family }\end{array}$ & $\begin{array}{c}\text { Genus in } \\
\text { each } \\
\text { Sub- } \\
\text { family }\end{array}$ & $\begin{array}{c}\text { No. of } \\
\text { Species in } \\
\text { the } \\
\text { collections }\end{array}$ & $\begin{array}{c}\text { No. of } \\
\text { species } \\
\text { known } \\
\text { from India }\end{array}$ & $\begin{array}{c}\text { \% } \\
\text { representation of } \\
\text { respective in the } \\
\text { collections }\end{array}$ \\
\hline $\begin{array}{l}\text { Dorcasominae } \\
\text { Spondylidinae }\end{array}$ & 2 & 3 & 0 & 4 & 0 \\
Cerambycinae & 26 & 4 & 0 & 6 & 9.7 \\
Lamiinae & 24 & 273 & 34 & 350 & 2.1 \\
Lepturinae & 4 & 18 & 2 & 1103 & 5.1 \\
Necydalinae & 1 & 1 & 0 & 20 & 10 \\
$\begin{array}{l}\text { Prioninae } \\
\text { Disteniinae }\end{array}$ & 10 & 29 & 14 & 57 & 0 \\
$\begin{array}{l}\text { (Disteniidae) } \\
\text { Philinae }\end{array}$ & 3 & 6 & 0 & 9 & 0 \\
(Vesperidae) & 1 & 2 & 1 & 3 & 3.6 \\
$\begin{array}{l}\text { All Longhorn } \\
\text { Beetles }\end{array}$ & $\mathbf{7 2}$ & $\mathbf{4 4 5}$ & $\mathbf{1 0 9}$ & $\mathbf{1 5 5 5}$ & $\mathbf{7}$ \\
\hline
\end{tabular}


Table.2 The total recorded species of longhorn beetles composition in each state and regions of the India from 1758 to 2016

\begin{tabular}{|c|c|c|c|c|}
\hline Region & State & $\begin{array}{l}\text { Species } \\
\text { Composition }\end{array}$ & $\begin{array}{l}\text { Species } \\
\text { Composition } \\
\text { against region } \\
(\%)\end{array}$ & $\begin{array}{l}\text { Species } \\
\text { composition } \\
\text { against India } \\
(\%)\end{array}$ \\
\hline \multirow{7}{*}{$\begin{array}{l}\text { North-Eastern India } \\
(592)\end{array}$} & Assam & 293 & 49.6 & 19.2 \\
\hline & Sikkim & 269 & 45.2 & 16.5 \\
\hline & Arunachal Pradesh & 115 & 19.4 & 7.4 \\
\hline & Meghalaya & 47 & 7.92 & 3.0 \\
\hline & Tripura & 27 & 4.56 & 1.7 \\
\hline & Manipur & 68 & 11.4 & 43.8 \\
\hline & Mizoram & 0 & 0 & 0 \\
\hline \multirow[t]{6}{*}{ Northern India (271) } & $\begin{array}{l}\text { Jammu and } \\
\text { Kashmir }\end{array}$ & 40 & 14.5 & 2.8 \\
\hline & Uttarakhand & 81 & 29.6 & 5.2 \\
\hline & Uttar Pradesh & 83 & 30.3 & 5.3 \\
\hline & Himachal Pradesh & 49 & 17.9 & 3.1 \\
\hline & New Delhi & 1 & 0.36 & 0.06 \\
\hline & Haryana & 0 & 0 & 0 \\
\hline \multirow[t]{6}{*}{ Southern India (435) } & Karnataka & 93 & 21.5 & 5.9 \\
\hline & Tamil Nadu & 293 & 67.2 & 18.7 \\
\hline & Kerala & 61 & 14.1 & 3.9 \\
\hline & Telangana & 5 & 1.2 & 0.3 \\
\hline & Andhra Pradesh & 3 & 0.7 & 0.2 \\
\hline & Pondicherry & 20 & 4.6 & 1.3 \\
\hline \multirow{2}{*}{ Central India (47) } & Madhya Pradesh & 25 & 53.2 & 1.6 \\
\hline & Chhattisgarh & 24 & 51.0 & 1.5 \\
\hline \multirow[t]{3}{*}{ Western India (49) } & Maharashtra & 49 & 100 & 3.1 \\
\hline & Gujarat & 0 & 0 & 0 \\
\hline & Goa & 2 & 4.2 & 0.1 \\
\hline \multirow[t]{4}{*}{ Eastern India (351) } & West Bengal & 339 & 97.4 & 21.8 \\
\hline & Bihar & 10 & 2.9 & 0.6 \\
\hline & Odisha & 12 & 3.4 & 0.8 \\
\hline & Jharkhand & 7 & 2.0 & 0.4 \\
\hline North West India (18) & Rajasthan & 3 & 6 & 0.2 \\
\hline \multirow[t]{2}{*}{ Indian Islands (122) } & Andaman Island & 122 & 100 & 7.8 \\
\hline & Lakshadweep & 0 & 0 & 0 \\
\hline India Orientalis (57) & British India & 57 & 100 & 3.6 \\
\hline $\begin{array}{l}\text { Inappropriate data } \\
\text { (159) }\end{array}$ & India & 159 & 100 & 10.2 \\
\hline
\end{tabular}


Table.3 The total recorded longhorn beetles species of the sub-family, tribes and genera in each state of India from 1758 to 2016

\begin{tabular}{|c|c|c|c|c|c|}
\hline $\begin{array}{l}\text { Sl. } \\
\text { No }\end{array}$ & Name of the State & $\begin{array}{c}\text { Number of Sub- } \\
\text { family }\end{array}$ & $\begin{array}{c}\text { Number of } \\
\text { Tribes }\end{array}$ & $\begin{array}{c}\text { Number of } \\
\text { Genara }\end{array}$ & $\begin{array}{c}\text { Genara } \\
\text { represented }(\%)\end{array}$ \\
\hline 1 & $\begin{array}{l}\text { Andaman and } \\
\text { Nicobar Island }\end{array}$ & 3 & 29 & 73 & 15 \\
\hline 2 & Andhra Pradesh & 1 & 2 & 2 & 0.4 \\
\hline 3 & Assam & 6 & 41 & 163 & 36.4 \\
\hline 4 & Arunachal Pradesh & 4 & 27 & 56 & 12.5 \\
\hline 5 & Bihar & 3 & 7 & 8 & 1.7 \\
\hline 6 & Chhattisgarh & 3 & 14 & 16 & 3.6 \\
\hline 7 & Goa & 2 & 2 & 3 & 0.7 \\
\hline 8 & Gujarat & 0 & 0 & 0 & 0 \\
\hline 9 & Himachal Pradesh & 7 & 23 & 37 & 8.2 \\
\hline 10 & $\begin{array}{l}\text { Jammu and } \\
\text { Kashmir }\end{array}$ & 6 & 17 & 31 & 6.9 \\
\hline 11 & Jharkhand & 2 & 3 & 4 & 0.9 \\
\hline 12 & Karnataka & 4 & 25 & 53 & 11.4 \\
\hline 13 & Kerala & 4 & 23 & 51 & 11.1 \\
\hline 14 & Madhya Pradesh & 4 & 18 & 23 & 5.1 \\
\hline 15 & Maharashtra & 5 & 22 & 28 & 6.2 \\
\hline 16 & Manipur & 6 & 27 & 44 & 9.8 \\
\hline 17 & Meghalaya & 3 & 14 & 19 & 4.2 \\
\hline 18 & Mizoram & 0 & 0 & 0 & 0 \\
\hline 19 & Nagaland & 1 & 1 & 3 & 0.7 \\
\hline 20 & New Delhi & 1 & 1 & 1 & 0.2 \\
\hline 21 & Odisha & 3 & 7 & 7 & 1.5 \\
\hline 22 & Pondicherry & 3 & 7 & 11 & 2.5 \\
\hline 23 & Punjab & 5 & 12 & 12 & 2.7 \\
\hline 24 & Rajasthan & 1 & 1 & 1 & 0.2 \\
\hline 25 & Sikkim & 4 & 41 & 144 & 32 \\
\hline 26 & Tamil Nadu & 4 & 46 & 142 & 31.2 \\
\hline 27 & Telangana & 2 & 3 & 4 & 0.9 \\
\hline 28 & Tripura & 3 & 18 & 21 & 4 \\
\hline 29 & Uttar Pradesh & 6 & 29 & 57 & 12.8 \\
\hline 30 & Uttarakhand & 7 & 28 & 46 & 10.2 \\
\hline 31 & West Bengal & 5 & 40 & 123 & 27.5 \\
\hline
\end{tabular}


Fig.1 Map indicating visited places for long horn beetles collection during the current investigation

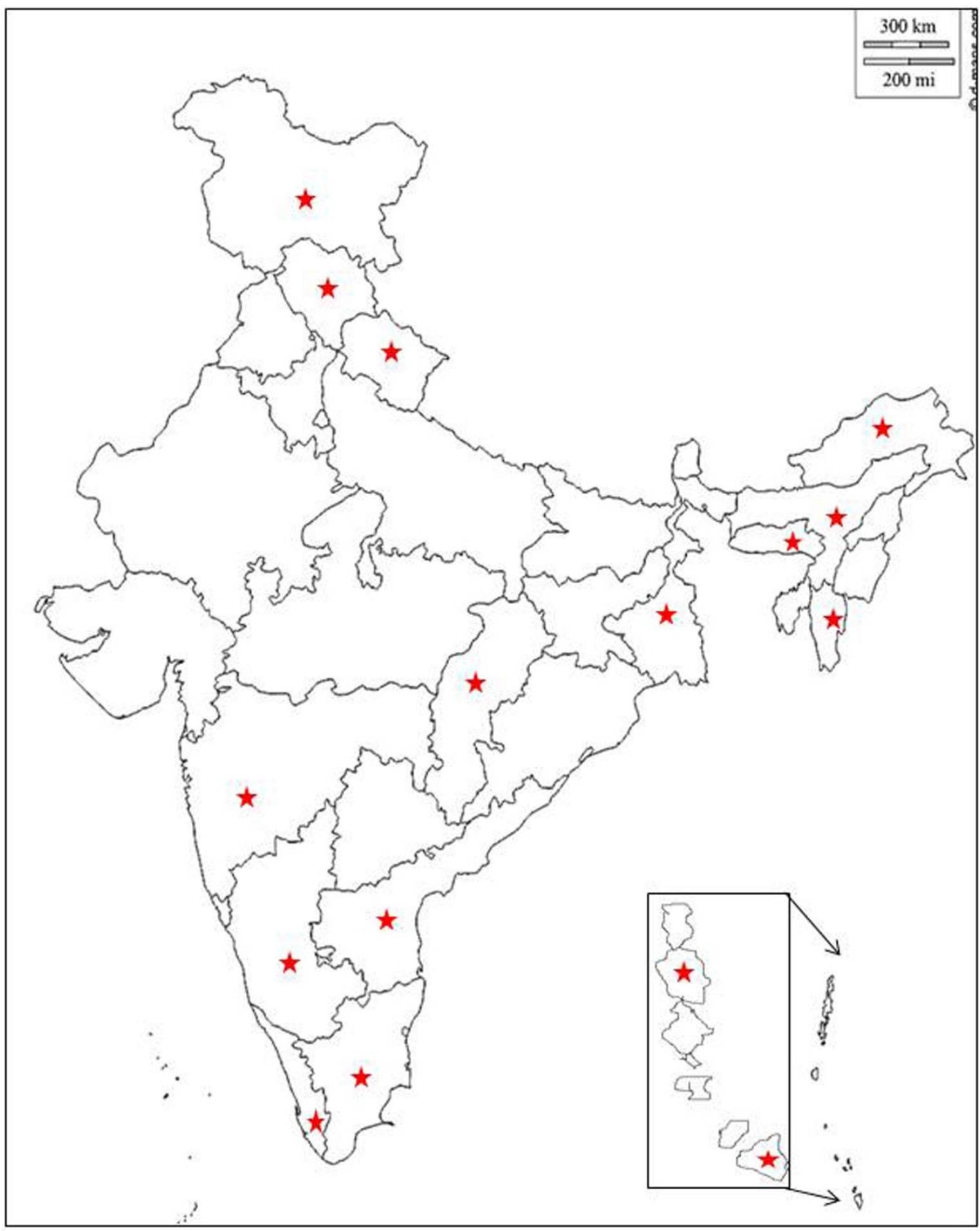


Fig.2 Region wise representation of longhorn beetles known from the India as listed in the checklist compiled

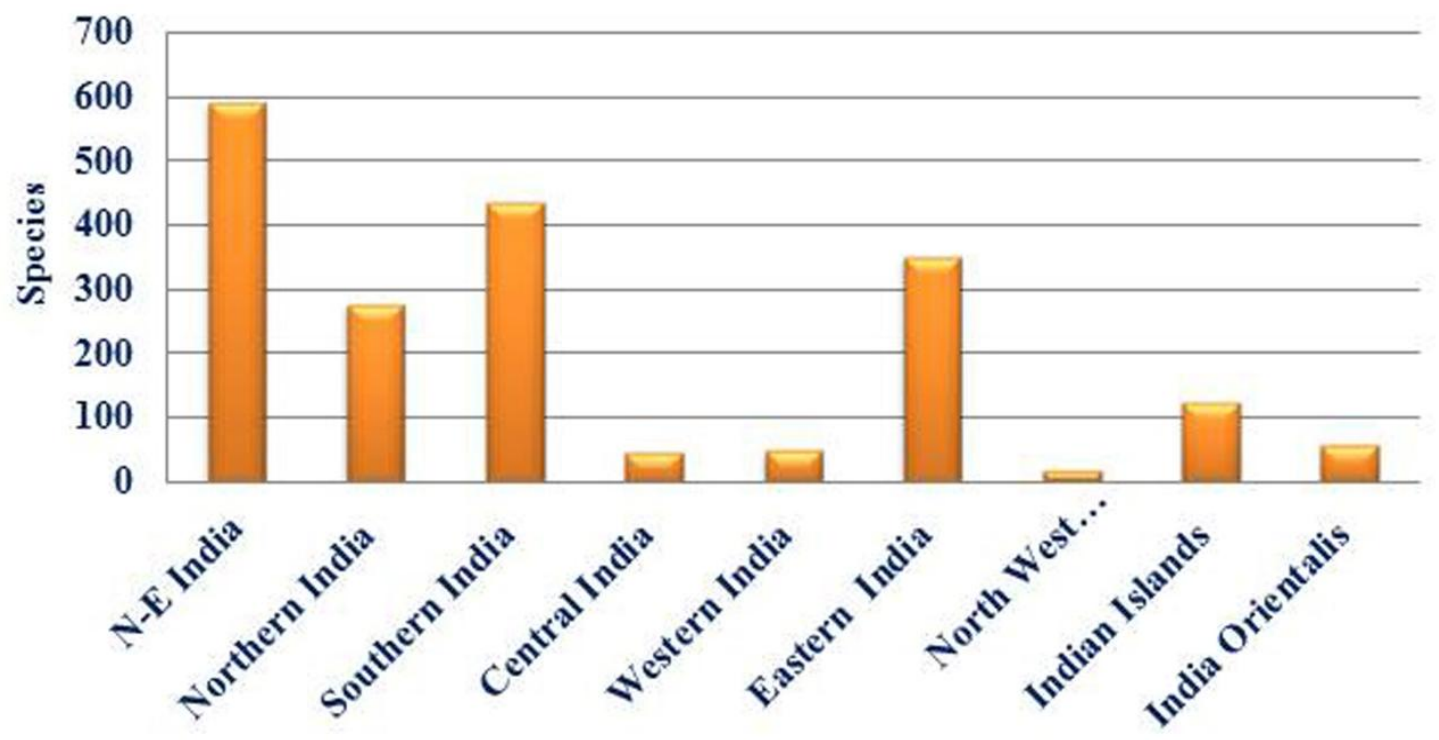

Fig.3 State wise representation of longhorn beetles known from the India as listed in the checklist compiled

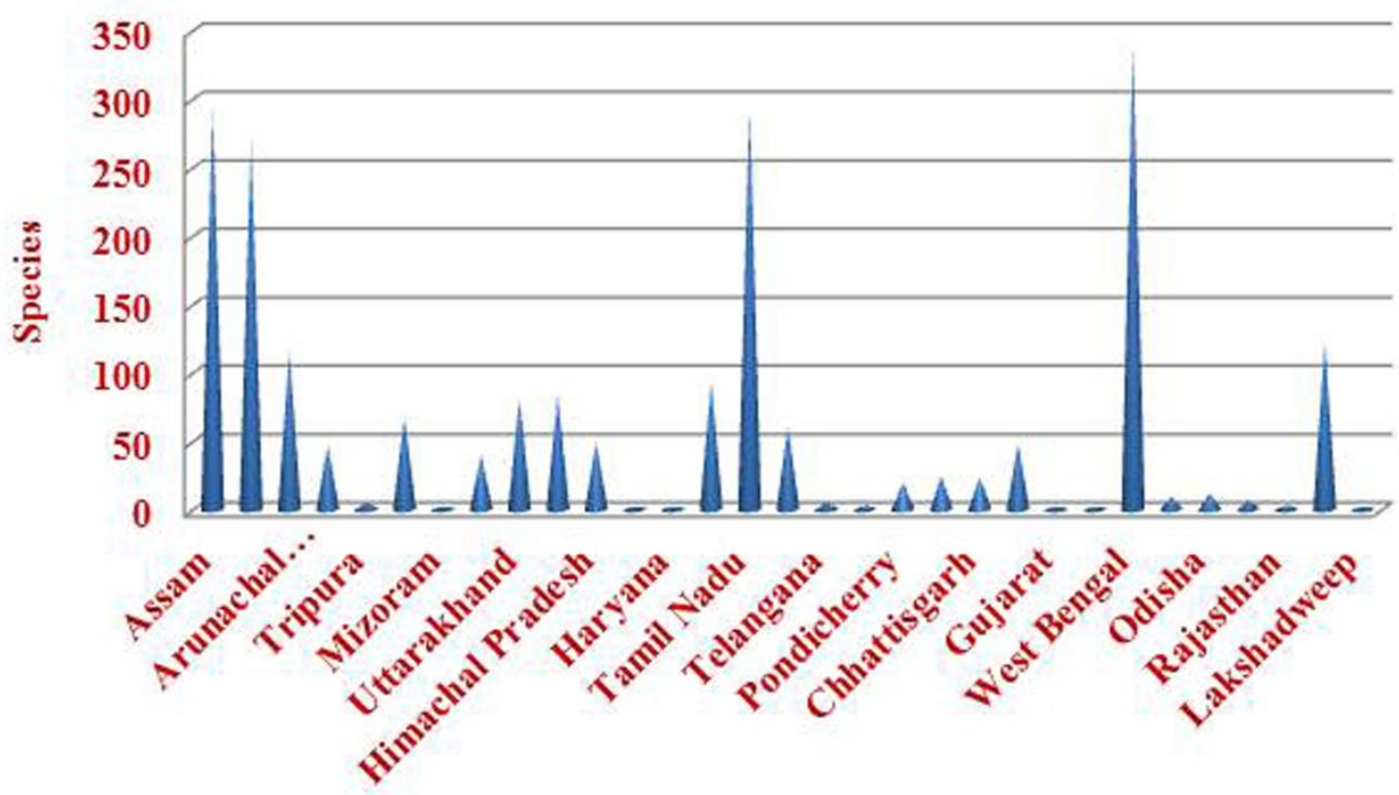


Fig.4 Area of India for better or poorly surveyed for long horn beetles as recorded up to 2016. A $=$ Area better studied; $\mathrm{B}=$ Area poorly studied

A.

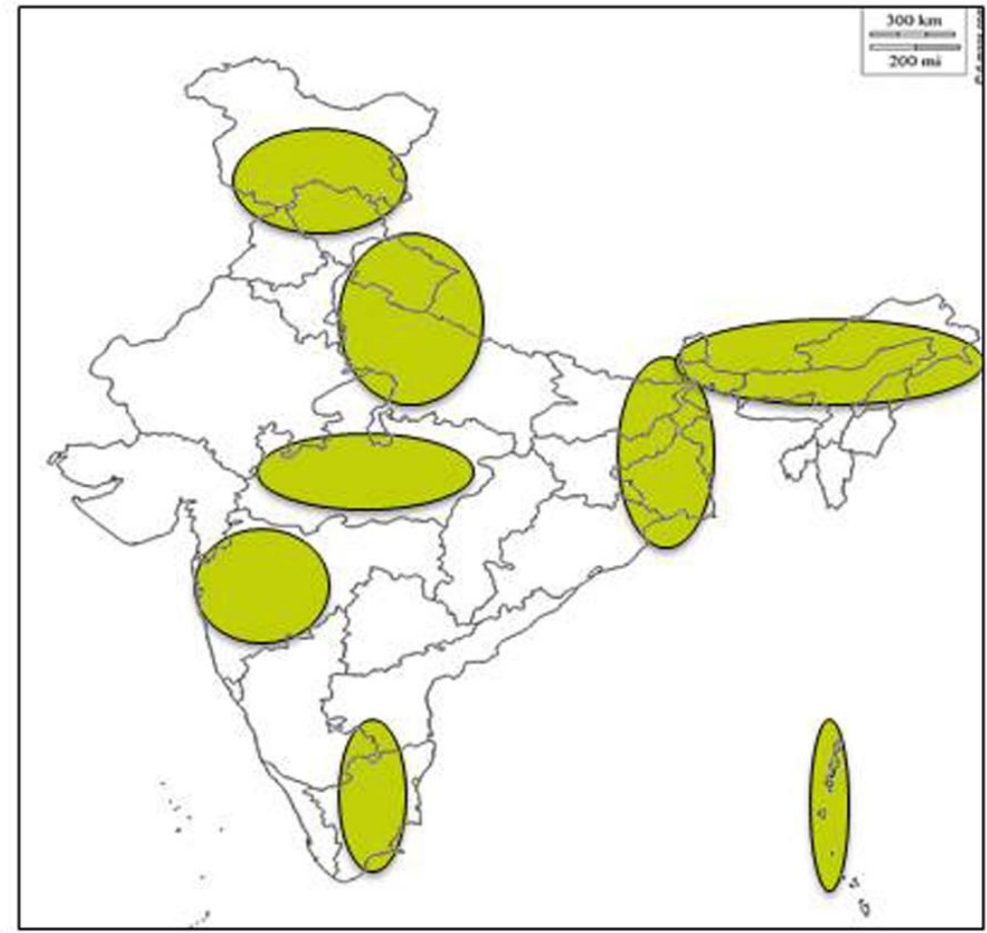

B.

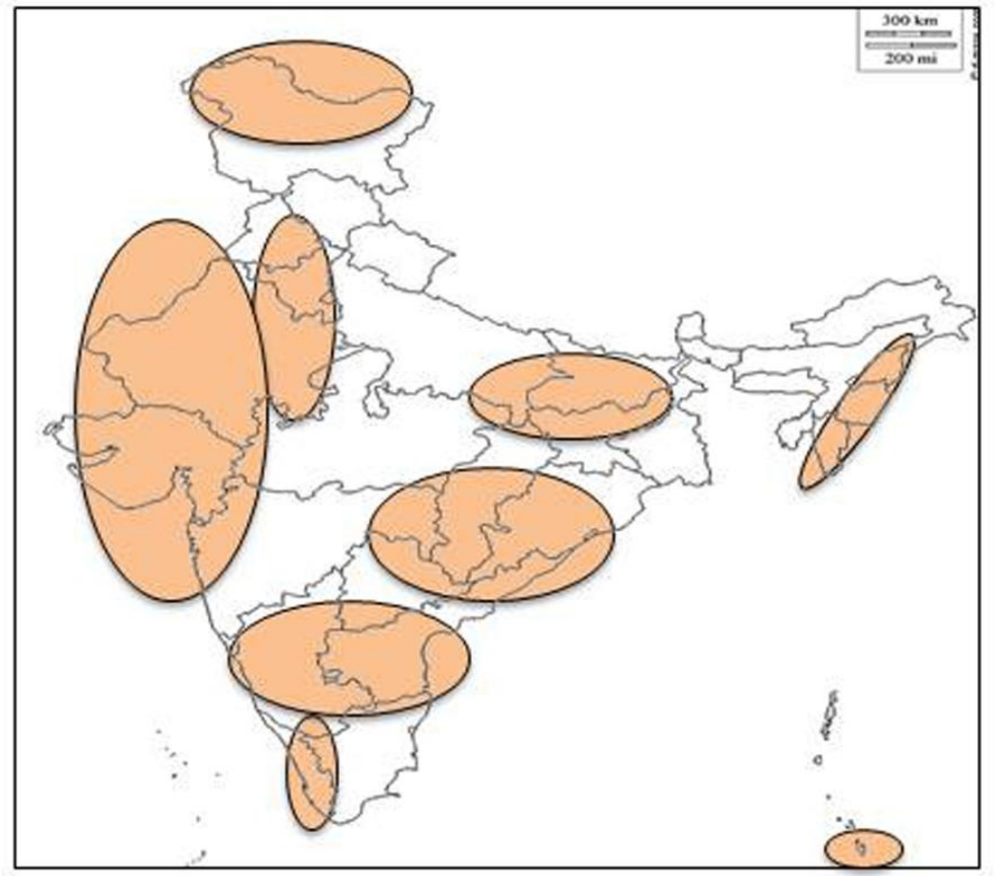

A full listing of all Indian species with synonyms and bibliographic citations with complete checklist includes 1555 valid species of longhorn beetles recorded so far from India (Kariyanna, 2016). Out of these many species, the region wise distribution are: 592 from North-Eastern states, 272 from Northern India, 431 from Southern India, 47 
from Central India, 48 from Western India, 348 from Eastern India, 18 from NorthWestern India, 57 from India Orientalis and 121 from Indian Islands (Fig. 2). The maximum number of species were recorded from North-Eastern India (38.1\%) (Table 2).

North-eastern states were extensively explored for their animals and plant diversity. This region is considered as one of the mega biodiversity areas. Still, there are many more species which are yet to be discovered from this region. Similary, the southern part including Tamil Nadu, Karnataka and Kerala were also fairly well covered $(28 \%$ of Cerambycid species) during British period. Nilgiris and Anamalai hill ranges were the important biodiversity hotspots for cerambycids in Tamil Nadu. Another biodiversity hotspot is Western Ghat that covering parts of Karnataka, Kerala and Maharashtra is also recorded a good number of Cerambycids species (Fig. 3).

A total of 159 longhorn species in the current checklist don't have further information (inappropriate data) on their collection locality and distribution information from India, so for the remaining species only, all further inferences were drawn (Tabl.2). Among the Indian states, the West Bengal alone accounted for over 22 per cent of the total known species of longhorns from India.

Tamil Nadu, Assam, Sikkim, Andaman and Nicobar Island, Arunachal Pradesh and Karnataka follows West Bengal and together (Fig. 3), these states accounted for more than 80 per cent of the species of Cerambycidae recorded from India. Chhattisgarh has only 24 and Karnataka has 93 recorded species of Cerambycidae on the basis of the Taxonomic records (Table 3 ).

Is there a real discrepancy in the way the species have been surveyed and identified? It was observed that some of the Indian region was better covered and some region was not at all surveyed for longhorn species. Hence, these regions / states require a thorough sampling of longhorns. The areas that were better sampled and those that were poorly sampled and the areas need a relook or resampling was indicated in figure $4 \mathrm{~A}$ and $\mathrm{B}$. Assam, Arunachal Pradesh and Sikkim, West Bengal, Madhya Pradesh, Maharashtra, Tamil Nadu, Karnataka, Himachal Pradesh, Uttarakhand, Uttar Pradesh and part of Jammu and Kashmir, and Andaman Island were fairly well studied (Fig. 4A). The rest of the states have only a handful of recorded species, especially from Rajasthan, Andhra Pradesh, Telangana, Bihar, Jharkhand, Goa and Nicobar Islands (Fig. 4B).

In conclusion, among the all animals longhorn beetles are more diverse and economically most important group of insects in the world. Their injury and damage to crop plant pose serious threat in agriculture production and marketing. With regarding to regional distribution, 592 are reported from NorthEastern states, 272 are from Northern India, 431 from Southern India, 47 from Central India, 48 from Western India, 348 from Eastern India, 18 from North-Western India, 57 from India Orientalis and 121 from the Indian Island region. The maximum number of the species was documented from NorthEastern states. The longhorns from West Bengal state were well studied and accounted over $22 \%$ of the known species of Cerambycidae from India.

\section{Acknowledgement}

The senior author acknowledges the distribution information provided for few species by Dr. Francesco Vitali, Luxemburg. Infrastructure facilities provided by the Director, ICAR-NBAIR, Bangalore and the support rendered by Head, Entomology, IGKV, Raipur are gratefully acknowledged. 


\section{References}

Agarwala, B.K., and Bhattacharjee, P.P. 2012. Long-horned Beetles (Coleoptera: Cerambycidae) and Tortoise Beetles (Chrysomelidae: Cassidinae) of Tripura, northeastern India with some new additions. J. Threatened Taxa, 4(13): 3223-3227.

Beeson, C.F.C. 1941. The Ecology and Control of the Forest Insects of India and the Neighbouring Countries.Aswant Singh, The Vasant Press, Dehra Dun, : i-ii +1-1007. (1961 reprint).

Berkov, A., and Tavakilian, G. 1999. Host utilization of the Brazil nut family (Lecythidaceae) by sympatric woodboring species of Palame (Coleoptera, Cerambycidae, Lamiinae, Acanthocinini). Biol. J. Linn. Soc., 67: 181-198.

Berkov, A., Meurer-Grimes, B., and Purzycki, K.L. 2000.Do Lecythidaceae specialist (Cole-optera, Cerambycidae) shun fetid tree species? Biotropica, 32: 440-451.

Bezark, L.G., Tyson, W.H., and Schiff, N.M. 2013. New species of Cerambycidae from Panama, with new distribution records (Coleoptera, Cerambycidae). Zootaxa, 3608(4): 273-277.

Delahaye, N. 2012.World catalogue of Prioninae.http://prioninae.org/Data/Catalo gue \%20Prioninae.pdf. Accessed 16October 2013.

Gahan, C.J. 1906. The Fauna of British India, including Ceylon and Burma. Coleoptera. - Vol. I. (Cerambycidæ). London, C. T. Bingham, : xviii +329 .

Ghate, H.V. and Agarwala, B.K. 2015. A first record of AbrynaregispetriPaiva, 1860 (Cerambycidae: Lamiinae: Pteropliini) and its redescription from India. $J$. Threatened Taxa, 7(14): 8173-8176.

Kariyanna, B. 2016. An analysis of the species diversity and distribution of agriculturally important longhorn beetles (Cerambycidae: Coleoptera) from india.
M.sc.(ag.) thesis, Department of Entomology, College of Agriculture, Raipur, Faculty of Agriculture, Indira Gandhi Krishi Vishvavidyalaya, Raipur, Chhattisgarh, pp. 557-588.

Kumawat, M.M., Singh, K.M., and Ramamurthy, V.V. 2015. A checklist of the Long-horned Beetles (Coleoptera: Cerambycidae) of Arunachal Pradesh, northeastern India with several new reports. J. Threatened Taxa, 7(12): 78797901.

Lawrence, J.F. 1982. Coleoptera. In Synopsis and Classification of Living Organisms, Vol. 2, S. P. Parker (ed.), McGraw-Hill, New York, 482-553.

Majumder, A., Raha, A., Mitra, B., and Chandra, K. 2015. New records of Cerambycidae (Insecta: Coleoptera) from Madhya Pradesh, India. J. Threatened Taxa, 7(15): 8242-8249.

Majumder, A., Raha, A., Mitra, B., Ghate, H.V., and Chandra, K. 2014. Contributions to the studies on Prioninae (Coleoptera: Cerambycidae) of Central India with checklist of Indian species Munis, Entomol. Zool., 9(2): 848-857.

Mitra, B. 2013. New records of longicorn beetle borers (Lamiinae: Cerambycidae: Coleoptera) from Little Nicobar Island, Indian Ocean. J. Andaman Sci. Assoc., 18(1): 123-124.

Mitra, B., Majumder, A., Das, P., and Chakraborti, U. 2015. An updated list of Cerambycidae (Coleoptera) with three new records from West Bengal. Entomol. Appl. Sci. Lett., 2(1): 3-8.

Mukhopadhyay, P. 2011. On a collection of Insecta: Coleopera: Cerambycidae and Curculionidae (Brachyderinae and Otiorrhynchinae) from Uttarakhand. Rec. Zool. Sury. India, 111(2): 75-88

Mukhopadhyay, P., and Biswas, S. 2000. Coleoptera: Cerambycidae. In: State Fauna Series 4, Fauna of Meghalaya: Part 5, State Fauna Series 4. Zoological 
Survey of India, Kolkata, India, 41-67.

Mukhopadhyay, P., and Halder, S.K. 2004.

Fauna of Manipur (part-2) Insects. Insecta: Coleoptera: Cerambycidae. State Fauna Series, 10: 421-431.

Namboodiri, M.P.S., and Thirumalai, G. 2009. Insecta: Coleoptera: Cerambycidae.

Zool. Surv. India, Fauna of Tamil Nadu, State Fauna Series, 17: 91-97.

Slipinski, S.A., and Escalona, H.E. 2013. Australian Longhorn Beetles (Coleoptera: Cerambycidae) Volume 1, Introduction and Subfamily Lamiinae. Csiro publishing, i-xviii +484 .

Stebbing, E.P. 1914. Indian Forest Insects of Economic Importance: Coleoptera. Eyre and Spottiswoode Ltd., London, 268-385. Švácha, P., and Lawrence, J.F. 2014. Cerambycidae. Handbook of Zoology, Coleoptera Volume 3: Morphology and Systematics (XX, Chrysomeloidea, Curculionoidea). in: Handbuch der Zoologie/Handbook of Zoology. Band/Volume IV Arthropoda: InsectaTeilband/Part 38. Coleoptera, Beetles. (eds) Beutel, R.G., Leschen, R.A.B. and Lawrence, J.F. Berlin, W. DeGruyter.

Zhang, Z.Q. 2011. An outline of higher-level classification and survey of taxonomic richness. Zootaxa, 3148, Magnolia Press, 7-12: 206-207.

\section{How to cite this article:}

Kariyanna, B., M. Mohan, Rajeev Gupta and Bakthavatchalam, N. 2017. Species Composition and Distribution Pattern of Longhorn Beetles across India. Int.J.Curr.Microbiol.App.Sci. 6(5): 1677-1688. doi: https://doi.org/10.20546/ijcmas.2017.605.182 